\title{
'Candidatus Xenohaliotis californiensis', a newly described pathogen of abalone, Haliotis spp., along the west coast of North America
}

\author{
Carolyn S. Friedman, ${ }^{1,2}$ Karl. B. Andree, ${ }^{2}$ K. A. Beauchamp, ${ }^{2}$ \\ James D. Moore, ${ }^{3}$ Thea T. Robbins, ${ }^{3}$ Jeffrey D. Shields ${ }^{4}$ \\ and Ronald P. Hedrick ${ }^{2}$
}
1 California Department of Fish \& Game, Bodega Marine Laboratory, PO Box 247, Bodega Bay, CA 94923, USA
2 Department of Medicine \& Epidemiology, School of Veterinary Medicine, University of California, Davis, CA 95616, USA
3 Bodega Marine Laboratory, PO Box 247, Bodega Bay, CA 94923, USA
4 Virginia Institute of Marine Science, Gloucester Point, VA 23062, USA

Author for correspondence: Carolyn S. Friedman. Tel: +1 707875 2067. Fax: +1 7078752009. e-mail: csfriedman@ucdavis.edu

\begin{abstract}
Withering syndrome is a fatal disease of wild and cultured abalone, Haliotis spp., that inhabit the west coast of North America. The aetiological agent of withering syndrome has recently been identified as a member of the family Rickettsiaceae in the order Rickettsiales. Using a combination of morphological, serological, life history and genomic (16S rDNA) characterization, we have identified this bacterium as a unique taxon and propose the provisional status of 'Candidatus Xenohaliotis californiensis'. The Gram-negative, obligate intracellular pleomorphic bacterium is found within membrane-bound vacuoles in the cytoplasm of abalone gastrointestinal epithelial cells. The bacterium is not cultivable on synthetic media or in fish cell lines (e.g. CHSE-214) and may be controlled by tetracyclines (oxytetracycline) but not by chloramphenicol, clarithromycin or sarafloxicin. Phylogenetic analysis based on the 16S rDNA of ' Candidatus Xenohaliotis californiensis' places it in the $\alpha$-subclass of the class Proteobacteria but not to the four recognized subtaxa of the $\alpha$-Proteobacteria $(\alpha-1, \alpha-2, \alpha-3$ and $\alpha-4)$. The bacterium can be detected in tissue squashes stained with propidium iodide, microscopic examination of stained tissue sections, PCR or in situ hybridization. ' Candidatus Xenohaliotis californiensis' can be differentiated from other closely related $\alpha$-Proteobacteria by its unique 16S rDNA sequence.
\end{abstract}

Keywords: Haliotis, pathogen, 'Candidatus Xenohaliotis californiensis', new taxon, abalone

\section{INTRODUCTION}

A relatively new disease, withering syndrome (WS), has resulted in catastrophic declines in populations of black abalone, Haliotis cracherodii Leach, in California, USA (Haaker et al., 1992; Steinbeck et al., 1992; VanBlaricom et al., 1993; Friedman et al., 1997). This chronic disease is also responsible for heavy losses of red abalone, Haliotis rufescens Swainson, in California, USA, and Baja California, Mexico (Haaker et al., 1995; Moore et al., 2000). Withering syndrome is characterized by degeneration of the digestive gland of the host (atrophy and/or

\footnotetext{
Abbreviations: WS, withering syndrome; RLP, Rickettsiales-like prokaryote; SP, Sobranes Point; VAFB, Vandenberg Airforce Base.

The GenBank accession number for the 16S rDNA gene sequence of 'Candidatus Xenohaliotis californiensis' is AF133090.
}

metaplasia) and depletion of glycogen reserves (Kismohandaka et al., 1993; Gardner et al., 1995). Animals cease feeding and catabolize foot muscle protein as an energy source that results in atrophy of the pedal muscle (Kismohandaka et al., 1993), and, ultimately, death. The incubation period of WS is approximately 5-7 months in black abalone (Friedman et al., 1997; Friedman \& Fan, 1998) and approximately 7-8 months in red abalone at $18^{\circ} \mathrm{C}$ (J. D. Moore \& C. $\mathrm{S}$. Friedman, unpublished results).

Until recently, an aetiological agent had not been identified. Gardner et al. (1995) suggested that a Rickettsiales-like prokaryote (RLP) that infects the mucosal epithelium of the gastrointestinal tract might be the causative agent of WS. Friedman \& Fan (1998) who transmitted the disease between black abalone observed a significant difference in intensity of RLP 
infection between abalone with and without WS, but no correlation between intensity of infection with RLPs and condition of the abalone in the infected treatments. In contrast, significant correlations were observed between intensity of RLP infection and degree of WS in wild and farmed red abalone (Haaker et al., 1995; Moore et al., 2000). The differences in responses to RLP infections between the two species may account for this discrepancy. Black abalone respond predominantly with degenerative changes to the digestive gland, while red abalone display a metaplasia of the mucosal epithelium in this gland. The metaplasia results in more target tissue for the bacterium compared to a loss of the same tissues in black abalone. In another study, Friedman et al. (unpublished results) found that both the RLPs and WS were responsive to treatments with oxytetracycline, providing strong evidence that the RLP is the aetiological agent of WS. Collectively, these studies indicate that the RLP in abalone is the aetiological agent of WS and that the pathogenesis of WS is complex and differs between host species.

Rickettsia-like bacteria are commonly observed in many marine invertebrates (Sparks, 1985; Friedman et al., 1989; LeGall et al., 1988). Until recently, these intracellular bacteria were thought to be nonpathogenic commensal organisms, unlike their terrestrial relatives (Anderson et al., 1992; Brenner et al., 1993). Due to the current inability to culture RLPs that infect marine invertebrates, differentiation of these bacteria has relied upon morphological characteristics as observed by light and electron microscopy methods (Friedman et al., 1989; VanBlaricom et al., 1993; Gardner et al., 1995; Bower et al., 1996; Wu \& Pan, 1999). Based on light and electron microscopy, the bacterium observed within membrane-bound cytoplasmic vacuoles of gastrointestinal epithelial cells of abalone resembled members of the tribe Ehrlichieae in the family Rickettsiaceae. In order to determine the relationship of the RLP in abalone to known members of the family Rickettsiaceae, we examined antigenic, physiological and life history characteristics and sequenced the 16S rDNA gene of the bacterium associated with WS in black abalone from California. The 16S rDNA has been exploited for developing primers for PCR (Andree et al., 2000) and in situ hybridization tests (Antonio et al., 2000) to detect the agent in abalone tissues.

\section{METHODS}

Animals. Adult black abalone that measured 76-127 mm were collected in July of 1996 from Vandenberg Airforce Base (VAFB), California, a location at which WS is found. Abalone free of WS that measured 51-76 mm were collected from Sobranes Point (SP), near Carmel, California in May of 1996.

Histology. In order to observe the morphology of RLP inclusions, selected tissues were placed in Invertebrate Davidson's solution (Shaw \& Battle, 1957) for $24 \mathrm{~h}$ and processed for routine paraffin histology. Deparaffinized $5 \mu \mathrm{m}$ sections were stained with haematoxylin and eosin or
Brown and Brenn's Gram stain (Luna, 1968) and viewed by light microscopy.

Transmission electron microscopy. The post-oesophagus was excised from several black abalone and $1-2 \mathrm{~mm}^{2}$ pieces were fixed in $4 \%$ glutaraldehyde, $0 \cdot 15 \mathrm{M}$ sodium cacodylate and $0 \cdot 15 \mathrm{M}$ sodium chloride, $\mathrm{pH} 7 \cdot 3$ for $2-18 \mathrm{~h}$ on ice, post-fixed in $1 \% \mathrm{OsO}_{4}$ for $1 \mathrm{~h}$ at $4{ }^{\circ} \mathrm{C}$ (Rosen et al., 1978). Tissues were rinsed twice in buffer, dehydrated through a graded series of acetone, infiltrated and embedded in epoxy resin. Ultrathin sections $(10-20 \mathrm{~nm})$ were stained with uranyl acetate and lead citrate and examined with a Zeiss $10 \mathrm{C}$ transmission electron microscope at $80 \mathrm{kV}$.

Antigenic reactivity with Chlamydiaceae-specific antibodies. The heteromorphic appearance of individual bacteria within some inclusions is suggestive of the distinct developmental stages (e.g. elemental and reticulate bodies) of Chlamydia and Chlamydophila spp., the two genera that now comprise the family Chlamydiaceae (Everett et al., 1999). Although other evidence suggested that the RLP is more closely related to members of the order Rickettsiales than to those in the order Chlamydiales, we tested the ability of two monoclonal antibodies that possess broad reactivity with species of Chlamydiaceae to recognize the RLP. The samples consisted of Invertebrate Davidson's-preserved deparaffinized tissue sections from two black abalone and one red abalone. Avian lung tissue infected with Chlamydia psittaci fixed in $10 \%$ neutral buffered formalin served as a positive control. The antibody (Mab AC-1; American Research Products) recognized a genus-specific epitope of the chlamydial lipopolysaccharide antigen. The second antibody we used (BIO29-65, Chlamydia Indirect IP KH, Bartels) recognizes all serovars of Chlamydia trachomatis, Chlamydophila (Chlamydia) psittaci and Chlamydophila (Chlamydia) pneumoniae. Both antibodies were used according to the manufacturer's protocols with indirect immunoperoxidase detection using 3-amino-9-ethylcarbazole as the chromogen. A section from each sample was incubated with normal mouse IgG in lieu of specific antibody as a negative control.

Antimicrobial susceptibility. Due to the inability to culture the RLP, antimicrobial susceptibility was evaluated in vivo using infected abalone. Both cultured red and wild black abalone infected with the RLP in the field were used as experimental animals. Abalone were administered the following antimicrobials in two trials: (1) daily intramuscular (IM) injections for $14 \mathrm{~d}$ : chloramphenicol (12 mg kg-1, Sigma, $n=8-10)$, clarithromycin $\left(1.96 \mathrm{mg} \mathrm{kg}^{-1}\right.$, Abbott Laboratories, $n=6-8$ ), sarafloxicin (12.98 mg kg-1, Abbott Laboratories, $n=6-8)$ and tetracycline (50 $\mathrm{mg} \mathrm{kg}^{-1}$, Sigma, $n=8-10$ ). (2) In a separate trial, abalone were administered nine IM doses of oxytetracycline $\left(21 \mathrm{mg} \mathrm{kg}^{-1}\right.$, LiquimycinLA 200, Pfizer, $n=9-12$; Table 1). Animals were sampled for histology as described above $1 \mathrm{~d}$ after administration of the final dose in the first trial and two weeks after the final dose in the second trial. The non-parametric Mann-Whitney Rank Sum test (SigmaStat version 2.03 1992-1997) was used to examine differences in prevalences of the bacterium between treated and untreated control groups.

Tissue selection and DNA extraction. A small piece of posterior oesophagus (post-oesophagus) was examined by phase-contrast microscopy to assess the degree of RLP infection in the VAFB animals and to assure that the SP abalone were RLP-free. The post-oesophagus from each abalone was individually rinsed $3 \times$ in sterile $3 \%(\mathrm{w} / \mathrm{v})$ saline $/ 0 \cdot 1 \%$ Tween 80 solution, followed by a rinse in sterile $3 \%$ saline to remove exogenous bacteria present in the 


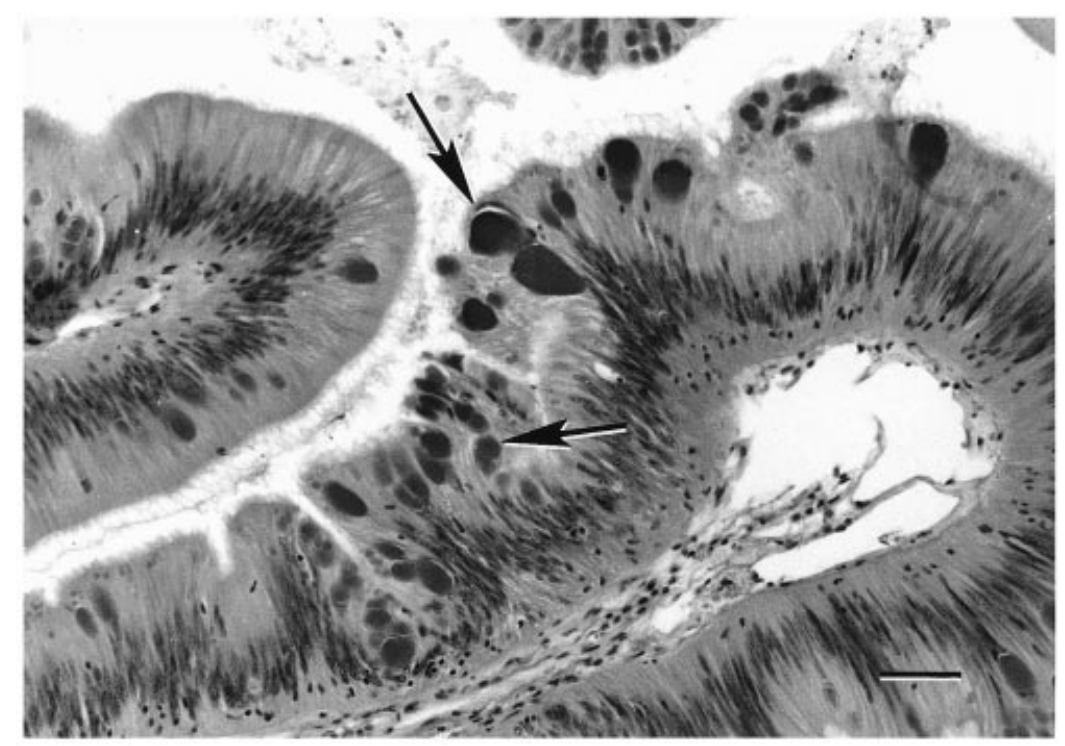

Fig. 1. RLPs (arrows) within posterior oesophagus of black abalone with withering syndrome. Note the homogeneous staining and apical location of the cytoplasmic vacuoles within host columnar epithelial cells. Haematoxylin and eosin. Bar, $50 \mu \mathrm{m}$.

lumen of the post-oesophagus. DNA was extracted according to the methods of Sambrook et al. (1989). Briefly, rinsed tissues were homogenized in lysis/proteinase $\mathrm{K}$ buffer. After $1 \mathrm{~h}$ at $55^{\circ} \mathrm{C}$ the DNA was extracted in a phenol/ chloroform solution. Isoamyl alcohol was added, mixed for $10 \mathrm{~min}$ and centrifuged. The top aqueous phase was removed and $0 \cdot 1$ vol. $3 \mathrm{M}$ sodium acetate was added. Cold $100 \%$ ethanol was added to precipitate the DNA. The pellet was washed once in $70 \%$ ethanol, air-dried and resuspended in Tris-EDTA (TE) buffer. The DNA concentration was determined by spectrophotometry.

PCR amplification and sequencing. A sample containing $150 \mathrm{ng}$ host and parasite DNA was used to amplify the RLP 16S rDNA sequence using EUB A and EUB B universal, eubacterial 16S rDNA primers (Gibco-BRL; Giovannoni, 1991). All the amplifications were performed in standard $50 \mu \mathrm{l}$ reactions containing $10 \mathrm{mM}$ Tris $/ \mathrm{HCl} \mathrm{pH} 8.3$ (at $25{ }^{\circ} \mathrm{C}$ ), $50 \mathrm{mM} \mathrm{KCl}, 1.5 \mathrm{mM} \mathrm{MgCl}, 0.001 \%$ (w/v) gelatin, $400 \mu \mathrm{M}$ dNTPs, $5 \mu \mathrm{M}$ tetramethyl ammonium chloride, 40 pmol each primer, and 2 U Taq polymerase. The PCR thermal cycler used was a model PTC-100 (MJ Research). The amplification entailed 37 cycles of $1 \mathrm{~min}$ at $94^{\circ} \mathrm{C}$, followed by $1 \mathrm{~min}$ at $56^{\circ} \mathrm{C}$, followed by $1 \mathrm{~min}$ at $72^{\circ} \mathrm{C}$. This was preceded by a denaturation step where samples were held at $95^{\circ} \mathrm{C}$ for $5 \mathrm{~min}$. The thermal cycler program finished with an extended elongation step where samples were held at $72{ }^{\circ} \mathrm{C}$ for $7 \mathrm{~min}$. An aliquot of the amplified DNA was separated on a $1.5 \%(\mathrm{w} / \mathrm{v})$ agarose gel, stained with ethidium bromide and examined using UV illumination. The entire RLP 16S rDNA gene (1525 bases) was cloned into pCR2.1 using a TOPO Cloning kit (Invitrogen) following the manufacturer's protocols. Clones were screened using PCR and primers that flanked the multi-cloning site of the vector. Clones were determined to be positive if they had the appropriate size insert in the plasmid ( $\sim 1600 \mathrm{bp})$. The $16 \mathrm{~S}$ rDNA gene from the clone designated p16RK3 was sequenced according to Andree et al. (1997) and aligned manually using Mac DNASIS software (Hitachi Software Engineering America).

Phylogenetic analysis. The sequence from clone p16RK3 was compared with data in GenBank using the BLAST algorithm (Altschul et al., 1990). The organisms with the highest ranking were used in our initial taxonomic charac- terization together with extant Rickettsiales-like bacteria from various taxa. We applied the methods of Jukes \& Cantor (1969) in performing evolutionary distance analysis with bootstrap support (500 replications) using MEGA software (Molecular Evolutionary Genetics Analysis version 1.01). This initial phylogenetic analysis used 1340 characters (or $\sim 86 \%$ ) of the $16 \mathrm{~S}$ rDNA gene (data not shown). Positions in which no homology was observed between species were omitted from the analysis. A second evaluation included only those organisms that were most proximal to the abalone RLP in our first evaluation. For this second analysis we included most of the 16S rDNA sequence (1496 bases or $98 \%$ of the abalone RLP gene) from the 15 most proximal species used in our first analysis. We eliminated only the most distal ends of the $16 \mathrm{~S}$ rDNA sequence such that the entire sequence of the shortest 16S rRNA gene deposited in GenBank served as the template for comparison. In addition, we deleted a large insertion of $\sim 150$ bases from the 16S rDNA gene of Caedibacter caryophila as this sequence was not shared with any of the other species in our study.

Accession numbers for nucleotide sequences. The $16 \mathrm{~S}$ rDNA gene sequences of selected bacteria were electronically retrieved from GenBank. These included: Anaplasma marginale, M60313; Caedibacter caryophila, X71837; Cowdria ruminantium, X61659; Coxiella burnetii, M21291; Ehrlichia sennetsu, M73225; Ehrlichia risticii, M21290; Ehrlichia phagocytophila, M73224; Ehrlichia bovis, U03775; Escherichia coli, J01695; NHP bacterium, U65509; Piscirickettsia salmonis, X60783; Rickettsia prowazekii, M21789; Rickettsia rickettsii, M21293; and Wolbachia pipientis, X61768.

\section{RESULTS}

\section{Histology}

The RLP stained Gram-negative and was observed within cytoplasmic vacuoles of abalone gastrointestinal epithelial cells. The bacterial inclusions were usually situated apical to the nucleus of the host cells (Fig. 1). The bacterium was found in cells of the postoesophagus, transport ducts of the digestive gland 

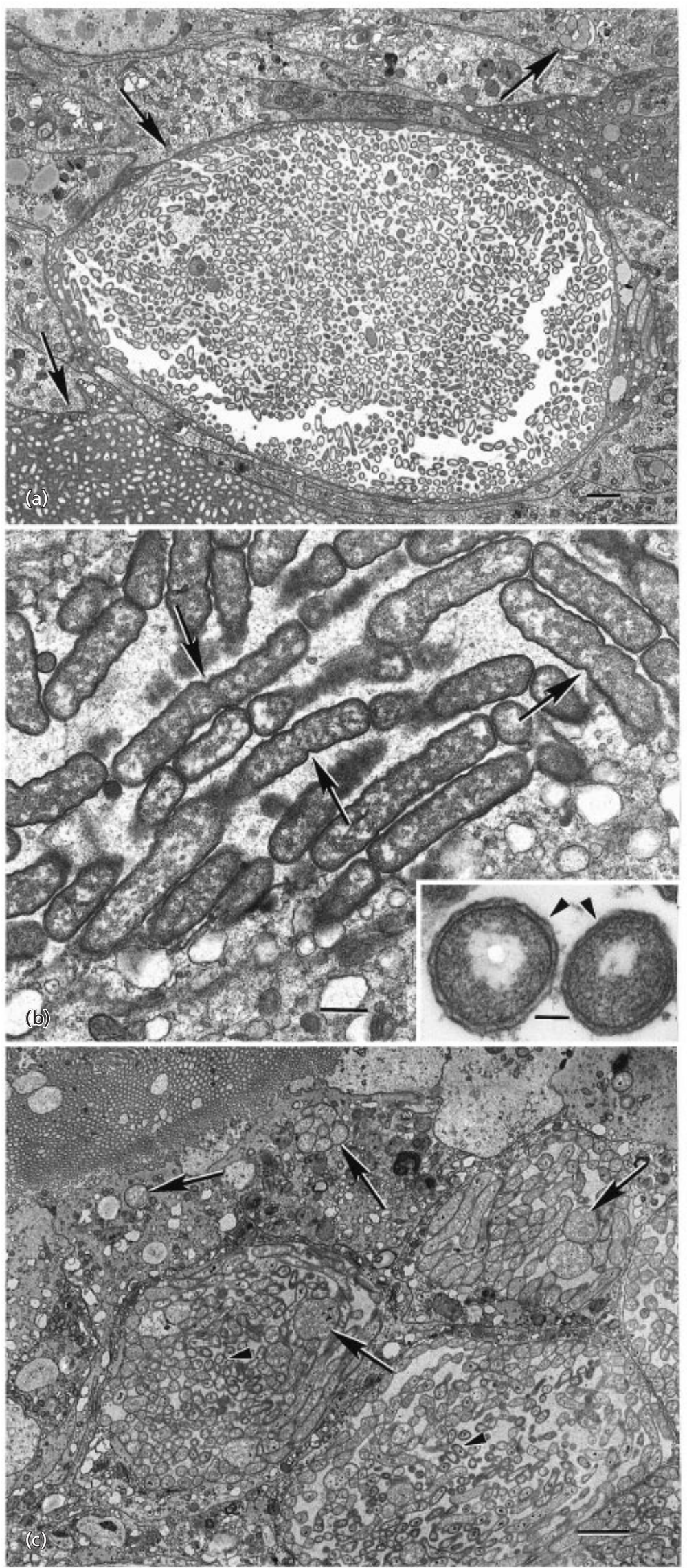

Fig. 2. (a) Transmission electron micrograph showing pleomorphic rod-shaped RLPs (arrows) within membrane-bound phagosomes of abalone gastrointestinal cells. Bar, $2 \mu \mathrm{m}$. (b) The bacterium divides by binary fission (arrows) and is emarginated by a trilaminar cell wall and lacks a visible peptidoglycan layer (inset: arrowhead). Ribosomes are located peripherally and fibrils of nucleoid material are centrally located. Bar, $500 \mathrm{~nm}$, inset: Bar, $100 \mathrm{~nm}$. (c) Inclusion containing heteromorphic bacteria. Arrows illustrate the larger spherical life stage that is predominantly observed in smaller phagosomes. The rod-shaped stage is denoted by an arrowhead. Bar, $2 \mu \mathrm{m}$. 
Table 1. In vivo testing of the susceptibility of red and black abalone to several antimicrobials administered by 9-12 intramuscular injections

\begin{tabular}{|c|c|c|}
\hline $\begin{array}{l}\text { Antimicrobial } \\
\text { Dose }\end{array}$ & $\begin{array}{l}\text { Percentage of } \\
\text { red abalone } \\
\text { with RLP foci }\end{array}$ & $\begin{array}{l}\text { Percentage of } \\
\text { black abalone } \\
\text { with RLP foci }\end{array}$ \\
\hline \multicolumn{3}{|c|}{ Chloramphenicol } \\
\hline None* & $90(n=10)$ & $100(n=8)$ \\
\hline $12 \mathrm{mg} \mathrm{kg}^{-1}$ & $80(n=10)$ & $87 \cdot 5(n=8)$ \\
\hline \multicolumn{3}{|l|}{ Clarithromycin } \\
\hline None & $100(n=8)$ & $100(n=6)$ \\
\hline $1.96 \mathrm{mg} \mathrm{kg}^{-1}$ & $100(n=8)$ & $100(n=6)$ \\
\hline \multicolumn{3}{|c|}{ Oxytetracycline (Liquimycin LA) } \\
\hline None & $100(n=10)$ & $100(n=8)$ \\
\hline $21 \mathrm{mg} \mathrm{kg}^{-1}$ & $\mathbf{0} \dagger(n=10)$ & $\mathbf{0} \dagger(n=9)$ \\
\hline \multicolumn{3}{|l|}{ Sarafloxacin } \\
\hline None & $100(n=8)$ & $100(n=6)$ \\
\hline $12 \cdot 98 \mathrm{mg} \mathrm{kg}^{-1}$ & $100(n=8)$ & $100(n=6)$ \\
\hline \multicolumn{3}{|l|}{ Tetracycline } \\
\hline None & $90(n=10)$ & $100(n=8)$ \\
\hline $50 \mathrm{mg} \mathrm{kg}^{-1}$ & $10 \$(n=10)$ & $\mathbf{0} \dagger(n=8)$ \\
\hline
\end{tabular}

* Control abalone were administered diluent ( $2 \%$ sterile saline) only.

$\dagger$ Treatments with rickettsial infection prevalences significantly less than that of controls $(p<0 \cdot 001)$, Mann-Whitney Rank Sum test.

\$ Treatments with rickettsial infection prevalences significantly less than that of controls $(p<0 \cdot 05)$, Mann-Whitney Rank Sum test.

and, less frequently, the intestine. The predominantly observed inclusion was spherical to oblong in shape, measured $14 \cdot 1-56 \cdot 4 \mu \mathrm{m}$ with a mean maximum dimension of $35.8 \pm 13.0 \mu \mathrm{m}$, and contained homogeneous and densely packed bacteria that stained deeply purple with haematoxylin and eosin (Fig. 1). No morulae were observed.

\section{Transmission electron microscopy}

The bacterium was pleomorphic and was found dividing within cytoplasmic vacuoles of host cells that appear to be phagosomes or phagolysosomes (Fig. 2). The bacterium is predominantly a slender, rod-shaped organism with a pleomorphic spherical to coccobacillus form observed primarily in smaller and, presumably, younger phagosomes (Fig. 2a). The rodshaped form replicates by binary fission and measures a mean of $332 \mathrm{~nm} \times 1550 \mathrm{~nm}$, with a range of 122 $598 \mathrm{~nm} \times 570-4460 \mathrm{~nm}$ (Fig. 2a, b). The spherical form measures a mean of $1405 \mathrm{~nm}$ in maximum dimension, with a range of $783-2190 \mathrm{~nm}$ (Fig. 2c). In addition, there appears to be an intermediate, coccobacillus size variant with a mean diameter of $620 \mathrm{~nm}(559-658 \mathrm{~nm})$ and length of $1270 \mathrm{~nm}$ (Fig. 2c). The bacterium is emarginated by a trilaminar cell wall that consists of an electron-dense inner plasma membrane and an outer membrane of equal electron density that are separated by an electron-lucent layer without a visible peptidoglycan layer (Fig. 2b). The outer cell wall, although wavy, lacks the intense rippling observed in members of the genus Ehrlichia. The bacterium contains many ribosomes, located around the periphery of the cell, and centrally located fibrils of nucleoid material (Fig. 2b insert). The bacterium lacks a slime layer that is observed surrounding rickettsiae in the typhus and spotted fever groups (Weiss \& Moulder, 1984a).

\section{Antigenic reactivity with Chlamydiaceae-specific antibodies}

No specific staining of the RLP inclusions was observed using either Chlamydiaceae-specific antibody or the preimmune mouse IgG. In contrast, the sections of avian lung infected with Chlamydophila (Chlamydia) psittaci had scattered positive (red) staining throughout the tissue (not shown).

\section{Antimicrobial susceptibility}

Microscopic examination of stained tissue sections from infected abalone treated with antimicrobials indicated that the RLP was only sensitive to the tetracyclines: oxytetracycline $(p<0 \cdot 001, n=9-12)$ and tetracycline $(p<0.05, n=8-10$, Table 1$)$. Administration of nine IM doses of $21 \mathrm{mg}$ oxytetracycline $\mathrm{kg}^{-1}$ effectively cured RLP infections in both red and black abalone (Table 1).

\section{$16 \mathrm{~S}$ rDNA sequence analysis}

A sequence alignment was made using the 16S rRNA sequences from p16RK 3 , and the 29 representative $\alpha$ and $\gamma$-Proteobacteria listed above that were used in a similar analysis of the shrimp NHP bacterium (Loy et al., 1996). The bacterial agent from abalone shares sequence motifs with the shrimp NHP bacterium but only $70.9 \%$ sequence similarity overall. A BLAST search analysis determined that the $16 \mathrm{~S}$ rDNA sequence of the abalone bacterium appears to be most closely related to those of Anaplasma marginale $(77.3 \%$ similarity), Ehrlichia bovis (75.8\%) and Wolbachia pipientis $(74.1 \%)$ when the entire $16 \mathrm{~S}$ sequence was used in the analysis (data not shown).

The abalone RLP appears to be equally distant from the other bacteria used in this study (Table 2). The phylogenetic distance analysis suggests a slightly different evolutionary relationship, but groups the RLP similar to the sequence similarity results from the BLAST search (Fig. 3). In both phylogenetic analyses performed, the abalone RLP is clearly unique and is most closely related to Wolbachia pipientis followed by Ehrlichia sennetsu and Ehrlichia risticii. Parsimony analyses using PAUP (Phylogenetic Analysis Using Parsimony, PAUP version 3.1) provided tree topologies which also indicated that the abalone RLP grouped 
Table 2. Genetic distance table illustrating the relationship of the WS bacterium and other Proteobacteria using MEGA

A total of 1496 nucleotides were included in the data set after missing information data and gaps were removed

\begin{tabular}{|c|c|c|c|c|c|c|c|c|c|c|c|c|c|c|}
\hline Taxon & 2 & 3 & 4 & 5 & 6 & 7 & 8 & 9 & 10 & 11 & 12 & 13 & 14 & 15 \\
\hline 1. WFS & $0 \cdot 1920$ & $0 \cdot 2884$ & $0 \cdot 2661$ & $0 \cdot 2040$ & $0 \cdot 2402$ & $0 \cdot 2101$ & $0 \cdot 2050$ & $0 \cdot 2392$ & $0 \cdot 2705$ & $0 \cdot 2307$ & $0 \cdot 2339$ & $0 \cdot 2245$ & $0 \cdot 2861$ & $0 \cdot 2952$ \\
\hline 2. Anaplasma marginale & & $0 \cdot 2060$ & $0 \cdot 1860$ & 0.0787 & $0 \cdot 1656$ & 0.0379 & $0 \cdot 0518$ & $0 \cdot 1637$ & $0 \cdot 1930$ & $0 \cdot 1762$ & $0 \cdot 1733$ & $0 \cdot 1346$ & $0 \cdot 2266$ & $0 \cdot 2255$ \\
\hline 3. Coxiella burnettii & & & $0 \cdot 2142$ & $0 \cdot 2224$ & $0 \cdot 2245$ & $0 \cdot 2131$ & $0 \cdot 2172$ & $0 \cdot 2224$ & $0 \cdot 2370$ & $0 \cdot 2101$ & $0 \cdot 2060$ & $0 \cdot 2203$ & $0 \cdot 1401$ & $0 \cdot 1791$ \\
\hline 4. Caedibacter caryophila & & & & $0 \cdot 1900$ & $0 \cdot 2101$ & $0 \cdot 1870$ & $0 \cdot 1949$ & $0 \cdot 2142$ & $0 \cdot 1551$ & $0 \cdot 1685$ & $0 \cdot 1656$ & $0 \cdot 2152$ & $0 \cdot 2091$ & $0 \cdot 2328$ \\
\hline 5. Cowdria ruminantium & & & & & $0 \cdot 1752$ & 0.0752 & 0.0855 & $0 \cdot 1733$ & $0 \cdot 2224$ & $0 \cdot 1723$ & $0 \cdot 1714$ & $0 \cdot 1355$ & $0 \cdot 2328$ & $0 \cdot 2487$ \\
\hline 6. Ehrlichia risticii & & & & & & $0 \cdot 1523$ & $0 \cdot 1598$ & $0 \cdot 0070$ & $0 \cdot 2091$ & $0 \cdot 1930$ & $0 \cdot 1900$ & $0 \cdot 1752$ & 0.2339 & $0 \cdot 2552$ \\
\hline 7. Ehrlichia phagocytophila & & & & & & & 0.0306 & $0 \cdot 1513$ & $0 \cdot 1949$ & $0 \cdot 1675$ & $0 \cdot 1656$ & $0 \cdot 1272$ & $0 \cdot 2193$ & $0 \cdot 2276$ \\
\hline 8. Ehrlichia bovis & & & & & & & & $0 \cdot 1579$ & $0 \cdot 2010$ & $0 \cdot 1762$ & $0 \cdot 1762$ & $0 \cdot 1336$ & $0 \cdot 2318$ & $0 \cdot 2307$ \\
\hline 9. Ehrlichia sennetsu & & & & & & & & & $0 \cdot 2080$ & $0 \cdot 1900$ & $0 \cdot 1870$ & $0 \cdot 1752$ & $0 \cdot 2328$ & $0 \cdot 2552$ \\
\hline 10. NHP bacterium & & & & & & & & & & $0 \cdot 1791$ & $0 \cdot 1752$ & $0 \cdot 2152$ & $0 \cdot 2392$ & $0 \cdot 2585$ \\
\hline 11. Rickettsia prowazekii & & & & & & & & & & & $0 \cdot 0101$ & $0 \cdot 1743$ & $0 \cdot 2091$ & $0 \cdot 2413$ \\
\hline 12. Rickettsia rickettsii & & & & & & & & & & & & $0 \cdot 1733$ & $0 \cdot 2091$ & $0 \cdot 2434$ \\
\hline 13. Wolbachia pipientis & & & & & & & & & & & & & $0 \cdot 2286$ & $0 \cdot 2307$ \\
\hline 14. Piscirickettsia salmonis & & & & & & & & & & & & & & $0 \cdot 1420$ \\
\hline 15. Escherichia coli & & & & & & & & & & & & & & \\
\hline
\end{tabular}

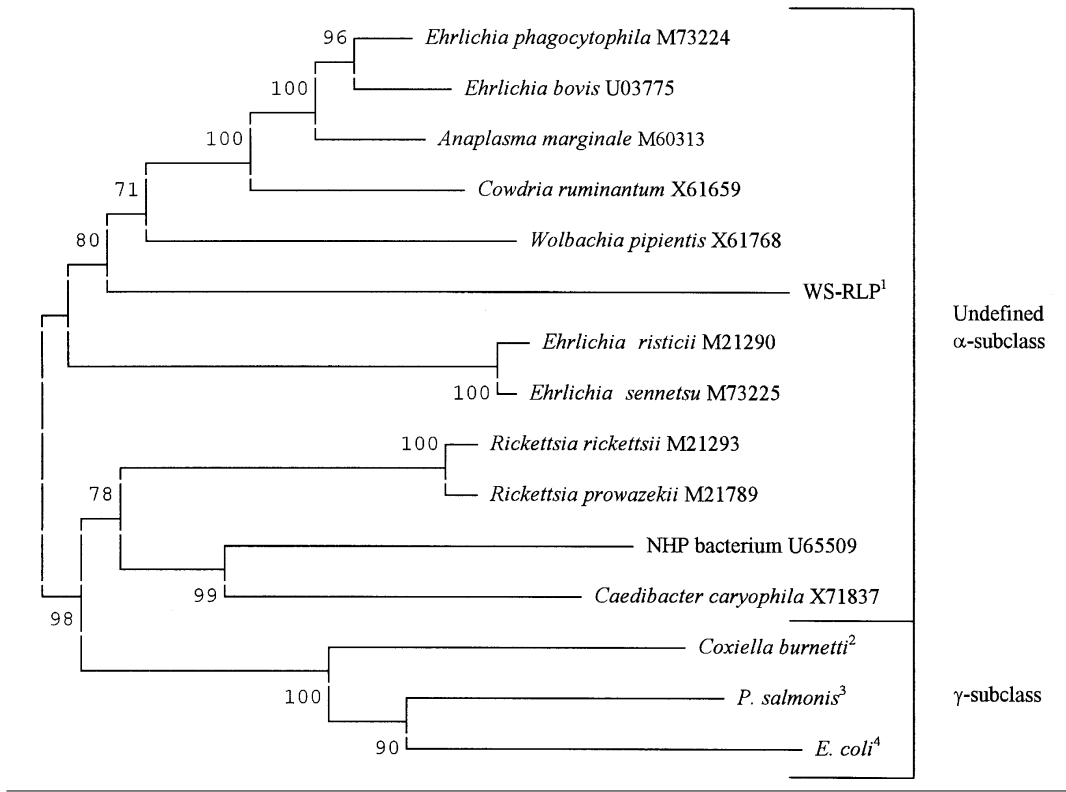

\begin{abstract}
Fig. 3. Dendrogram showing evolutionary relationship of the abalone RLP (WS-RLP) to members of the families Rickettsiaceae and Piscirickettsiaceae with Escherichia coli as a representative genetically distant bacterium. The number at branch points represents the percentage occurrence of a given branch during 500 replicates of the bootstrap analysis. Each bar is approximately equal to a distance of 0.002668 . Superscript numbers denote the following sequence accession numbers: 1, AF133090; 2, M21291; 3, $\mathrm{X} 60783 ; 4, \mathrm{~J} 01695$.
\end{abstract}

most closely with Ehrlichia risticii and Ehrlichia sennetsu (data not shown). Collectively, these data illustrate the uniqueness of the $16 \mathrm{~S}$ rDNA sequence of the abalone RLP.

\section{DISCUSSION}

Wayne et al. (1987) recommended that bacterial nomenclature should reflect genomic relationships. Confirmatory phenotypic data should also be sought prior to the introduction of a new name (Nelson et al., 1984). Recent bacterial taxonomy has increasingly relied on both phenotypic and genomic information including a new species in the genus Rickettsia, Rickettsia japonica (Uchida et al., 1992) and in the genus Nocardia, Nocardia crassostreae (Friedman et al., 1998). Those bacteria that cannot be cultured provide fewer phenotypic characters and therefore phylogenetic analyses become central to taxonomic placement. Based on proposals by Murray \& Schleifer (1994) and Murray \& Stackebrandt (1995; the provisional status of Candidatus was created for unculturable organisms and poorly characterized organisms, e.g. 'Candidatus Arsenophonus tristoninarum', Hypsa \& Dale, 1997). Despite this, several species of Ehrlichia have been described based principally upon genomic sequences such as Ehrlichia chaffeensis (Anderson et al., 1991), Ehrlichia ewingii (Anderson et al., 1992) and Ehrlichia muris (Wen et al., 1995). Ehrlichia chaffeensis was differentiated largely on its unique $16 \mathrm{~S}$ rRNA sequence. Phylogenetic analyses using $16 \mathrm{~S}$ sequence analysis have been used to unify two genera: Bartonella and Rochalimea in the family Bartonellaceae, and to remove the family Bartonellaceae from the order Rickettsiales (Brenner et al., 1993). We used a combination of morphological, tinctorial, physiological, pathological and genomic traits to identify the bacterium associated with WS in 
abalone as a previously undescribed bacterium in the family Rickettsiaceae and propose inclusion in the provisional status, Candidatus with the name of 'Candidatus Xenohaliotis californiensis'.

The RLP that infects abalone is a small, Gramnegative, pleomorphic bacterium that forms large intracytoplasmic inclusions within gastrointestinal epithelial cells. These inclusions lack the morphology of morulae (Fig. 1), characteristic of the genus Ehrlichia. The bacterium is an obligate intracellular parasite as evidenced by unsuccessful culture on artificial media (C. S. Friedman \& R. P. Hedrick, unpublished results). Collectively, these traits confirm placement of the abalone RLP in the order Rickettsiales. Tissue-specificity of the abalone RLP resembles that of Rickettsia spp. or Anaplasma marginale which often infect the midgut of arthropod vectors (Ribeiro et al., 1996). Anaplasma marginale also infects blood cells of its mammalian host, as do members of the genus Ehrlichia (Anderson et al., 1991; Ribeiro et al., 1996; Ristic \& Huxsoll, 1984). Wolbachi pipientis infects germinal cells and epithelia of the insect vector (mosquito), while Wolbachi melophagi is observed in the lumina of the host (sheep) gastrointestinal tract (Weiss et al., 1984). Host-specificity and transmission of the abalone RLP is unique as this type of bacterium has not previously been described in a marine gastropod and transmission is direct (Friedman et al., 1997) as suggested for Piscirickettsia salmonis, a marine agent that infects salmon (Fryer et al., 1992). The abalone bacterium is pleomorphic with multiple size variants as observed in some genera of rickettsiae. For example, the life cycle of Coxiella burnetii and Cowdria ruminantium includes a vegetative and relatively electron-lucent large cell variant and a small cell variant that is quite electron-dense (Weiss \& Moulder, 1984b; Jongejan et al., 1991). Bonami \& Pappalardo (1980) observed a dimorphic, membrane-bound, intracytoplasmic rickettsia which is pathogenic to the crab, Carcinus mediterraneus. The life cycle of this crab pathogen also included an electron-dense small-cell variant and a larger and more electron-lucent cell variant. The progression of size variants suggests that this is a single species with a dimorphic life history as observed in other members of the family Rickettsiaceae. In addition, the rickettsia found in abalone lacks a visible peptidoglycan layer that is often lacking in rickettsial bacteria (e.g. Ehrlichia spp.; Kawahara et al., 1993). However, the outer cell wall of the abalone bacterium lacks the intense rippling observed in members of the genus Ehrlichia. The RLP from abalone lacked a slime layer found in Rickettsia spp. in the typhus and spotted fever groups (Weiss \& Moulder, 1984a). In addition, pan-Chlamydia antibodies did not recognize the abalone RLP. These traits illustrate the unique morphology and life history of the RLP that infects abalone relative to described members of the family Rickettsiaceae.

Using rRNA sequence analyses, Weisburg et al. (1989) determined that the family Rickettsiaceae is poly- phyletic and is comprised three tribes: Rickettsiaea, Ehrlichieae and Wolbachieae. Our study indicates that the abalone RLP shares similarities with members of all three tribes but is phylogenetically distinct from each tribe. Evolutionary relationships to other rickettsiae shown in the distance table (Table 2) and dendrogram (Fig. 3) illustrate that the 16S rDNA of the abalone RLP is a member of the $\alpha$-subclass of the class Proteobacteria. Like other members of the family Rickettsiaceae in the $\alpha$-subclass, the bacterium does not belong to the four recognized subtaxa of the $\alpha$ Proteobacteria $(\alpha-1, \alpha-2, \alpha-3$ and $\alpha-4$; Fig. 3). This information clearly differentiates the abalone RLP from the $\gamma$-subclass of the class Proteobacteria that includes genera such as Coxiella and Piscirickettsia. In addition, members of the genus Rickettsia form a monophyletic group within the $\alpha$-subclass that is distinct from the abalone RLP and four genera (Ehrlichia, Wolbachia, Cowdria and Anaplasma) with which it forms a polyphyletic group. As illustrated in Fig. 3, the $16 \mathrm{~S}$ rDNA sequence of the abalone RLP represents a lineage that is distinct from the other genera within this group. As shown in our study, vanVliet et al. (1992) also found that despite differences in morphology and host and target cell preferences, Cowdria ruminantium and Ehrlichia canis and Ehrlichia chaffeensis form a closely related cluster upon analysis of $16 \mathrm{~S}$ gene sequences. Collectively, these traits in conjunction with a lack of the full complement of phenotypic data required for validation of a new genus and species, we propose the name, 'Candidatus Xenohaliotis californiensis' (Xe'no.ha.li.o.tis' L. fem. n. xeno foreign; Haliotis generic name of its abalone host; N.L. fem. n. Xenohaliotis a foreign organism in abalone; cal'i.for.ni.en.sis. N.L. fem. adj. californiensis regarding California, USA, the area where the organism was initially identified).

\section{Description of ' Candidatus Xenohaliotis californiensis'}

Gram-negative, periodic acid-Schiff base stain-negative, pleomorphic coccobacillus, $\sim 332 \times 1550 \mathrm{~nm}$ with an irregular spherical cell stage $\sim 1450 \mathrm{~nm}$ in maximum dimensions. Stains basophilic with haematoxylin and eosin. Non-motile. Gram-negative cell wall that lacks visible peptidoglycan and slime layers, ribosome rich with fibrilar nucleoid. Replicates within spherical to oblong, intracytoplasmic membrane-bound vacuoles of abalone gastrointestinal transport or absorptive epithelium. Bacteria-filled vacuoles are generally located distal to host nucleus. Not cultivable on synthetic media or in fish cell lines (e.g. CHSE-214, American Type Culture Collection). Sensitive to tetracyclines but not to chloramphenicol, clarithromycin or sarafloxicin. Based on 16S rDNA sequence analysis, the bacterium is a member of the undefined $\alpha$-subclass of the class Proteobacteria. The bacterium can be diagnosed with tissue squashes stained with propidium iodide, microscopic examination of stain tissue sections and can be differentiated from other closely 
related $\alpha$-Proteobacteria by its unique 16S rDNA sequence.

\section{ACKNOWLEDGEMENTS}

This work was supported by the Saltonstall-Kennedy Program of the National Oceanic and Atmospheric Administration, US Department of Commerce under grant number NA76FD0046. Additional support was provided by the California State Resources Agency, California Department of Fish and Game and the Aquaculture and Fisheries Program, University of California, Davis.

\section{REFERENCES}

Altschul, S. F., Gish, W., Miller, W., Meyers, E. W. \& Lipman, D. J. (1990). Basic local alignment search tool. J Mol Biol 215 , 403-410.

Anderson, B. E., Dawson, J. E., Jones, D. C. \& Wilson, K. H. (1991). Ehrlichia chaffeensis, a new species associated with human ehrlichiosis. J Clin Microbiol 29, 2838-2842.

Anderson, B. E., Greene, C. E., Jones, D. C. \& Dawson, J. E. (1992). Ehrlichia ewingii sp. nov., the etiological agent of canine granulocytic erhlichiosis. Int J Syst Bacteriol 42, 299-302.

Andree, K. B., Gresoviac, S. J. \& Hedrick, R. P. (1997). Small subunit ribosomal RNA sequences unite alternate actinosporean and myxosporean stages of Myxobolus cerebralis, the causative agent of whirling disease in salmonid fish. $J$ Eukaryot Microbiol 44, 208-215.

Andree, K. B., Friedman, C. S., Moore, J. D. \& Hedrick, R. P. (2000). A polymerase chain reaction for detection of genomic DNA of a Rickettsiales-like prokaryote associated with Withering Syndrome in Black Abalone (Haliotis cracherodii). J Shellfish Res (in press).

Antonio, D. B., Andree, K. B., Moore, J. D., Friedman, C. S. \& Hedrick, R. P. (2000). Detection of Rickettsiales-like prokaryotes (RLPs) by in situ hybridization in black abalone Haliotis cracherodii with Withering Syndrome. J Invertebr Pathol 75 (in press).

Bonami, J. R. \& Pappalardo, R. (1980). Rickettsial infection in marine crustacea. Experientia 36, 180-181.

Bower, S. M., Meyer, G. R. \& Boutillier, J. A. (1996). Stained prawn disease (SPD) of Pandalus platyceros in British Columbia, Canada, caused by a rickettsial infection. Dis Aquat Org 24, 41-54.

Brenner, D., O'Connor, S. P., Winkler, H. K. \& Steigerwalt, A. G. (1993). Proposals to unify the genera Bartonella and Rochalimea, with descriptions of Bartonella quintana comb. nov., Bartonella vinsonii comb. nov., Bartonella henselae comb. nov., and to remove the family Bartonellaceae from the order Rickettsiales. Int J Syst Bacteriol 43, 777-786.

Brock, J. A., Nakagawa, L. K., Hayashi, T., Teruya, S. \& VanCampen, H. (1986). Hepatopancreatic rickettsial infection of the penaeid shrimp, Penaeus marginatus (Randall), from Hawaii. J Fish Dis 9, 73-77.

Everett, K. D. E., Bush, R. M. \& Andersen, A. A. (1999). Emended description of the order Chlamydiales, proposal of Parachlamydiaceae fam. nov. and Simkaniaceae fam. nov., each containing one monotypic genus, revised taxonomy of the family Chlamydiaceae, including a new genus and five new species, and standards for the identification of organisms. Int $J$ Syst Bacteriol 49, 415-440.

Friedman, C. S. \& Fan, T. W.-M. (1998). Withering Syndrome of black abalone: Causes and physiological alterations. In
California Sea Grant Reports of Completed Projects 1994-97, pp. 101-106. La Jolla, CA: Sea Grant College System.

Friedman, C. S., McDowell, T., Groff, J. M., Hollibaugh, J. T., Manzer, D. \& Hedrick, R. P. (1989). Presence of Bonamia ostreae among populations of the European flat oyster, Ostrea edulis Linné, in California, USA. J Shellfish Res 8, 133-137.

Friedman, C. S., Thomson, M., Chun, C., Haaker, P. L. \& Hedrick, R. P. (1997). Withering syndrome of the black abalone, Haliotis cracherodii (Leach): water temperature, food availability, and parasites as possible causes. $J$ Shellfish Res 16, 403-411.

Friedman, C. S., Beaman, B. L., Chun, J., Goodfellow, M., Gee, A. \& Hedrick, R. P. (1998). Nocardia crassostreae sp. nov., the causal agent of nocardiosis in Pacific oysters. Int J Syst Bacteriol 48, 237-246.

Fryer, J. L., Lannan, C. N., Giovannoni, S. J. \& Wood, N. D. (1992). Piscirickettsia salmonis gen. nov., sp. nov., the causative agent of an epizootic disease in salmonid fishes. Int $J$ Syst Bacteriol 42, 120-126.

Gardner, G. R., Harshbarger, J. C., Lake, J. L., Sawyer, T. K., Price, K. L., Stephenson, M. D., Haaker, P. L. \& Togstad, H. A. (1995). Association of procaryotes with symptomatic appearance of withering syndrome in black abalone, Haliotis cracherodii. $J$ Invertebr Pathol 66, 111-120.

Giovannoni, S. (1991). The polymerase chain reaction. In Nucleic Acid Techniques in Bacterial Systematics, pp. 177-201. Edited by E. Stackebrandt \& M. Goodfellow. New York: Wiley.

Haaker, P. L., Richards, D. V., Friedman, C. S., Davis, G. E., Parker, D. O. \& Togstad, H. (1992). Mass mortality and withering syndrome in black abalone Haliotis cracherodii in California. In Abalone of the World, pp. 214-224. Edited by S. A. Shephard, M. J. Tegner \& S. A. Guzman del Proo. Oxford: Blackwell.

Haaker, P. L., Harris, S. L., Taniguchi, I. K. \& Friedman, C. S. (1995). Withering syndrome in California: does it occur in subtidal populations? J Shellfish Res 14, 267.

Hypsa, V. \& Dale, C. (1997). In vitro culture and phylogenetic analysis of "Candidatus Arsenophonus triatominarum", an intracellular bacterium from the triatomine bug, Triatoma infestans. Int J Syst Bacteriol 47, 1140-1144.

Jongejan, F., Zandbergen, T. A., van de Wiel, P. A., de Groot, M. \& Uilenberg, G. (1991). The tick-borne rickettsia Cowdria ruminantium has Chlamydia-like developmental cycle. Onderstepoort J Vet Res 58, 227-237.

Jukes, T. H. \& Cantor, C. R. (1969). Evolution of protein molecules. In Mammalian Protein Metabolism, vol. 3, pp. 21-132. Edited by H. N. Munro. New York: Academic Press.

Kawahara, M., Suto, C., Rikihisa, Y., Yamamoto, S. \& Tsuboi, Y. (1993). Characterization of ehrlichial organisms isolated from a wild mouse. J Clin Microbiol 31, 89-96.

Kismohandaka, G., Friedman, C. S., Roberts, W., Hedrick, R. P. \& Crosby, M. P. (1993). Investigation of physiological parameters of black abalone with withering syndrome. J Shellfish Res 12,131-132.

LeGall, G., Chagot, D., Mialhe, E. \& Grizel, H. (1988). Branchial rickettsiales-like infection associated with a mass mortality of sea scallop Pecten maximus. Dis Aquat Org 4, 229-232.

Loy, J. K., Dewhirst, F. E., Weber, W., Frelier, P. F., Garbar, T. L., Serban, I. T. \& Templeton, J. W. (1996). Molecular phylogeny and in situ detection of the etiological agent of necrotizing helpatopancreatitis in shrimp. Appl Environ Microbiol 62, 3439-3445.

Luna, L. G. (editor) (1968). Manual of Histologic Staining Methods of the Armed Forces Institute of Pathology, 3rd edn, pp. 38-39. New York: McGraw-Hill. 
Moore, J. D., Robbins, T. T. \& Friedman, C. S. (2000). Withering syndrome in farmed red abalone, Haliotis rufescens: thermal induction and association with a gastrointestinal Rickettsialeslike prokaryote. J Aquat Anim Health 12, 26-34.

Murray, R. G. E. \& Schleifer, K. H. (1994). Taxonomic notes: a proposal for recording the properties of putative taxa of procaryotes. Int J Syst Bacteriol 44, 174-176.

Murray, R. G. E. \& Stackebrandt, E. (1995). Taxonomic note: implementation of the provisional status Candidatus for incompletely described procaryotes. Int $J$ Syst Bacteriol $\mathbf{4 5}$, 186-187.

Nelson, D. C., Waterbury, J. B. \& Jannasch, H. W. (1984). DNA base composition and genome size of the prokaryotic symbiont in Riftia pachyptila (Pogonophora). FEMS Microbiol Lett 24, 267-271.

Ribeiro, M. F. B., Lima, J. D. \& Salcedo, J. H. P. (1996). Attempted transmission of Anaplasma marginale by infected Boophilus microplus. Arq Bras Med Vet Zootec 48, 397-402.

Ristic, M. \& Huxsoll, D. L. (1984). Tribe II. Ehrlichiae Philip 1957, 948 ${ }^{\mathrm{AL}}$. In Bergey's Manual of Systematic Bacteriology, vol. 1, pp. 704-711. Edited by N. R. Krieg \& J. G. Holt. Baltimore: Williams \& Wilkins.

Rosen, M. D., Stasek, C. R. \& Herman, C. O. (1978). The ultrastructure and evolutionary significance of the cerebral ocelli of Mytilus edulis, the bay mussel. The Veliger 21, 10-18.

Sambrook, J., Fritsch, E. F. \& Maniatis, T. (1989). Molecular Cloning : a Laboratory Manual, 2nd edn. Cold Spring Harbor, NY: Cold Spring Harbor Laboratory.

Shaw, B. L. \& Battle, H. I. (1957). The gross and microscopic anatomy of the digestive tract of the oyster, Crassostrea virginica (Gmelin). Can J Zool 35, 325-347.

Sparks, A. K. (1985). Rickettsiae, chlamydiae, and mycoplasmas of invertebrates. In Synopsis of Invertebrate Pathology Exclusive of Insects, pp. 165-180. New York: Elsevier.

Steinbeck, J. R., Groff, J. M., Friedman, C. S., McDowell, T. \& Hedrick, R. P. (1992). Investigation into a coccidian-like protozoan from the California abalone, Haliotis cracherodii. In Abalone of the World, pp. 203-213. Edited by S. A. Shephard, M. Tegner \& S. Guzman del Proo. Oxford: Blackwell.

Sudhir, K., Tamura, K. \& Nei, M. (1993). MEGA: Molecular Evolutionary Genetic Analysis, version 1.01. Pennsylvania State University, University Park, PA 16802, USA.
Uchida, T., Uchiyama, T., Kumano, K. \& Walker, D. H. (1992). Rickettsia japonica sp. nov., the etiological agent of spotted fever group rickettsiosis in Japan. Int $J$ Syst Bacteriol 42, 303-305.

VanBlaricom, G. R., Ruediger, J. L., Friedman, C. S., Woodard, D. D. \& Hedrick, R. P. (1993). Discovery of withering syndrome among black abalone Haliotis cracherodii Leach, 1814 populations at San Nicolas island, California. J Shellfish Res 12, 185-188.

vanVliet, A. H. M., Jongejan, F. \& van der Zeijst, B. A. M. (1992). Phylogenetic position of Cowdria ruminatum (Rickettsiales) determined by analysis of amplified $16 \mathrm{~S}$ ribosomal DNA sequences. Int J Syst Bacteriol 42, 494-498.

Wayne, L. G., Brenner, D. J., Cowell, R. R. \& 9 other authors (1987). International Committee on Systematic Bacteriology. Report of the ad hoc committee on reconciliation of approaches to bacterial systematics. Int J Syst Bacteriol 37, 463-464.

Weisburg, W. G., Dobson, M. E., Samuel, J. E. \& 7 other authors (1989). Phylogenetic diversity of the rickettsiae. J Bacteriol 171, 4202-4206.

Weiss, E. \& Moulder, J. W. (1984a). Genus I. Rickettsia da Rocha-Lima 1916, 567 AL (Nom. Gen. Cons. Opin. 19, Jud. Comm. 1958, 158). In Bergey's Manual of Systematic Bacteriology, vol. 1, pp. 688-698. Edited by N. R. Kreig \& J. G. Holt. Baltimore: Williams \& Wilkins.

Weiss, E. \& Moulder, J. W. (1984b). Genus III. Coxiella (Philip 1943) Philip 1948, 58 $\mathrm{AL}$. In Bergey's Manual of Systematic Bacteriology, vol. 1, pp. 701-704. Edited by N. R. Krieg \& J. G. Holt. Baltimore: Williams \& Wilkins.

Weiss, E., Dasch, G. A. \& Chang, K.-P. (1984). Tribe III. Wolbachieae Philip, 1956, 266 ${ }^{\mathrm{AL}}$. In Bergey's Manual of Systematic Bacteriology, vol. 1, pp. 711-713. Edited by N. R. Kreig \& J. G. Holt. Baltimore: Williams \& Wilkins.

Wen, B., Rikihisa, Y., Mott, J., Fuerst, P. A., Kawahara, M. \& Suto, C. (1995). Ehrlichia muris sp. nov., identified on the basis of $16 \mathrm{~S}$ rRNA base sequences and serological, morphological, and biochemical characteristics. Int J Syst Bacteriol 45, 250-254.

Wu, X. \& Pan, J. (1999). Studies on Rickettsia-like organism disease of the tropical marine pearl oyster. I. The fine structure and morphogenesis of Pinctada maxima pathogen Rickettsialike organism. J Invertebr Pathol 73, 162-171. 